\title{
Effect of teat order on piglet rearing results of native Złotnicka White breed
}

\author{
Ewa Skrzypczak', Karolina Szulc', Marek Babicz² and Janusz T. Buczyński \\ 'Department of Pig Breeding and Production, Poznań University of Life Sciences, Poznań, Poland, ${ }^{2}$ Department of Pig \\ Breeding and Production Technology, University of Life Sciences in Lublin, Lublin, Poland
}

\begin{abstract}
Observations of animal behaviour during the first three weeks of life revealed the existence of a specific correlation between the use of individual teats by suckling piglets and successive pairs of teats. Therefore, it appeared justified to undertake experiments with the aim to study relationships between the use of teats by individual piglets and the results of their rearing, focusing in particular on small-sized domestic breeds. The experimental animal material comprised 20 litters which derived from 20 randomly selected sows of a native swine breed. The scope of the performed observations and analyses of parameters included: frequency of approaching the preferred teats, number and body weight of piglets, body weight gains as well as mortality of piglets throughout the rearing period.

It was found that teat location exerted influence on the mass, body weight gain and death of the experimental piglets. The performed observations demonstrated that the teats of the 2nd and 3rd pairs were those which were most frequently used by piglets, whereas the last teats situated close to the tail were used less frequently, mainly by marginal animals. The best rearing results were recorded for the piglets which used teats situated in the front part of the sow body. In addition, it was also found that piglets' mortality was the greatest when the animals suckled from teats situated at the rear part of the sow body. The performed analysis of milk production also confirmed that it was highest from teats situated in the front part of the sow body.
\end{abstract}

Keywords: milk yield, teat order, native breeds, sow, piglet rearing 


\section{Introduction}

Poland is a country known for a long tradition with respect to the protection of animals genetic resources.

In Poland, the State Programme of Protection of Genetic Resources embraces the total of 87 native populations of farm animals (Górecki 2003, Rosiński et al. 2006, Szulc et al. 2012). Utilisation of native breeds supports the maintenance of biodiversity (Komosa \& Purzyc 2009). Pigs of indigenous breeds are also important from the point of view of their associations with traditions, history and culture of local communities and furthermore, are characterised by a number of features which distinguish them from commercial, high-production breeds and lines (Skrzypczak et al. 2012).

Sows' milk production as well as their ability to feed consecutive litters constitutes one of very important factors affecting their reproductive potentials as well as their usefulness for continued maintenance. It should also be remembered that the composition of colostrum and milk as well as their quantities are individual traits of each sow (Devillers et al. 2007, Beyga \& Rekiel 2009).

Therefore, proper handling of sows during the perinatal period as well as during lactation, care taken for the condition of the sow for the best possible quality of colostrum and milk were important since all these factors exert a decisive influence on health, viability, activity and body weight gain of piglets (King et al. 1997, Jensen et al. 1998, Wähner et al. 2001, Rooke \& Bland 2002, Le Dividich et al. 2005, Beyga \& Rekiel 2010).

Rearing results of piglets as well as their suitability for further breeding also depend on both environmental factors such as daily care and the applied system of maintenance as well as on genetic factors (Stabenow \& Manteuffel 2002, Burri et al. 2009, Baxter et al. 2011, Eliasson \& Isberg 2011, Vanheukelom et al. 2012). It should also be remembered that the size of a litter is affected by the number of teats in gilts and that is why animals with 14 or more teats should be chosen for future mothers in the course of the selection process (Kim et al. 2005, Tvrdon \& Humpolicek 2010).

Unfortunately, the observed rearing results continue to remain on an unsatisfactory level as, on average, up to $20 \%$ of born piglets die during the period from parturition to weaning (Pejsak 2006, Lundgren 2011, Quesnel 2011).

Observations made so far clearly indicate that rearing results of piglets and their development depend on the steat order«.

Therefore, the objective of the performed experiments was to determine interrelationships between the use of individual teats in sows by piglets and rearing results.

\section{Material and methods}

\section{Animals}

The experimental animal material subjected to analyses included 20 litters derived from 20 randomly selected sows of the indigenous breed Złotnicka White (only one litter derived from each sow). All sows were multiparous in the third lactation.

Experiments were carried out during the period from September 2010 to August 2011 on an agricultural farm in the neighbourhood of Poznań, Wielkopolska Region, in which the 
farmer keeps swine of native breeds. All experimental sows were kept on one farm and in one piggery.

The experimental sows were housed in the same conditions which met all the welfare requirements. The sows were housed in single farrowing crates from about the 10th day before parturition to the end of the 3rd week of lactation. The sows were fed individually twice a day with standard mixture according to Polish Nutrient Requirements for Pigs (1993). Water was available ad libitum. The composition of the experimental diet is presented in Table 1.

Table 1

Chemical composition and energetic value of experimental mixture for sows

\begin{tabular}{lll}
\hline No. & Nutrients & Value \\
\hline 1. & Metabolic energy & $12.94 \mathrm{MJ}$ min. \\
2. & Crude protein & $16.00 \% \mathrm{~min}$. \\
3. & Crude fibre & $7.50 \% \mathrm{max}$. \\
4. & Crude ash & $4.80-6.80 \%$ min.-max. \\
5. & Crude fat & $4.20-6.20 \%$ min.-max. \\
6. & Ca & $1.00 \% \min$. \\
7. & $P$-digestible & $0.32 \% \min$. \\
8. & Na & $0.20 \% \mathrm{~min}$. \\
9. & Lysine & $0.93 \% \mathrm{~min}$. \\
10. & Methionine & $0.26 \% \mathrm{~min}$. \\
11. & Met.+Cyst. & $0.54 \% \mathrm{~min}$. \\
12. & Tryptophan & $0.16 \% \mathrm{~min}$. \\
13. & Threonine & $0.64 \% \mathrm{~min}$. \\
\hline
\end{tabular}

All sows in the experiment were mated naturally and the progeny from 20 litters derived from one father, a pure-bred White Złotnicki boar. Throughout the duration of the trial, mothers' milk was the only feed of piglets and they were not fed additionally by any concentrate. The total of 213 born piglets was analysed.

\section{Research analyses}

Surveillance of piglet behaviour during suckling of colostrum and milk was carried out using direct observations by the direct, non-participating method for periods necessary to secure reliable results.

In the applied research method, the reliable results comprised time-period that was necessary to monitor the behaviour of animals, to take down notes and it amounted to 13 hours per day $(13 \mathrm{~h} /$ day). The scope of the performed observations and analyses of parameters included: frequency of approaching the preferred teats; number and body weight of piglets on days 1, 7, 14 and 21; body weight gain of individual piglets in periods from day 1 to 7, from day 8 to 14 and from day 15 to 21 as well as mortality of piglets throughout the rearing period, i.e. from day 1 to 21 of life. Teats were numbered in the order beginning from front legs towards the rear legs (1L, 1R, 2L, 2R, 3L, 3R, 4L, 4R, 5L, 5R, 6L, 6R, 7L, 7R). 
In order to make observations of the piglets' behaviour easier during the process of parturition, each piglet was marked on its back according to a scheme elaborated by the authors. This scheme was applied in each of the observed litters.

\begin{tabular}{|c|c|}
\hline $\begin{array}{l}\text { No. OF } \\
\text { PIGLET }\end{array}$ & SYMBOL \\
\hline 1 & \\
\hline 2 & \\
\hline 3 & \\
\hline 4 & \\
\hline 5 & 1 \\
\hline 6 & \\
\hline 7 & I \\
\hline 8 & \\
\hline 9 & \\
\hline 10 & \\
\hline 11 & \\
\hline 12 & \\
\hline 13 & \\
\hline 14 & \\
\hline 15 & 1 \\
\hline
\end{tabular}

Scheme 1

\section{Statistical analyses}

The obtained research data were processed statistically using for this purpose an SAS package v. 8.11 (SAS Institute Inc., Cary, NC, USA) and applying the following methods:

1) normal distribution test (UNIVARIATE);

2) multifactorial analysis of variance using PROC, GLM and LSM (the comparisons comprised: body weight, growth rate, mortality of piglets as well as milk production depending on the preference for individual teats);

3) the obtained results were presented as least square means (LSM) and standard errors (SE);

4) for variables which were discrete random variables, a probit transformation was applied described by Żuk (1989) and Lynch \& Welsh (1998) which makes it possible to change discrete random variables into continuous random variables;

5) milk production of experimental sows from individual teats was calculated indirectly employing the following formula, according to Williams 1995:

Piglet weight on day 21 - Piglet weight on day $1 \times 3.8 \mathrm{~kg}$

The analysis of variance was carried out on the basis of the following model:

$$
Y_{i j k l m n}=\mu+t_{i}+s_{j}+p_{k}+c_{l}+a_{m}+f+e_{i j k l m n}
$$

Where $Y$ is the measured value of the trait, $\mu$ is the population mean, $t_{i}$ is the fixed effect of ith teat $(1 \mathrm{~L}, 1 \mathrm{R}, 2 \mathrm{~L}, 2 \mathrm{R}, 3 \mathrm{~L}, 3 \mathrm{R}, 4 \mathrm{~L}, 4 \mathrm{R}, 5 \mathrm{~L}, 5 \mathrm{R}, 6 \mathrm{~L}, 6 \mathrm{R}, 7 \mathrm{~L}, 7 \mathrm{R}), s_{i}$ is the effect of jth sows $(1-20), p_{k}$ is the effect of $k$-th piglet sex (1: male; 2 : female), $c$, is the effect of the Ith canal in teat (1:2-canal; 2: 3-canal), $a_{m}$ is the effect of the $m$-th season of the year (1: autumn; 2 : winter; $3:$ spring; 4: summer), $f$ is the effect of the litter father and $e_{i j k l m n}$ is the effect of random error. 


\section{Results}

Observations of piglets regarding their preferences for individual teats are presented in Figure 1. It was observed that piglets sucked teats of the second and third pairs most readily (average use: $92.5 \%$ and $92 \%$, respectively). It should be emphasised, that the most active piglets used teats situated in the front part of the sow body. Moreover, it is also worth to say that throughout the rearing period, no deaths among piglets which selected the second and third pair of teats for suckling were recorded (Figure 2). The highest mortality was recorded in the case of pair seven (7L: $28.57 \%$ and 7R: $36.37 \%$ ).

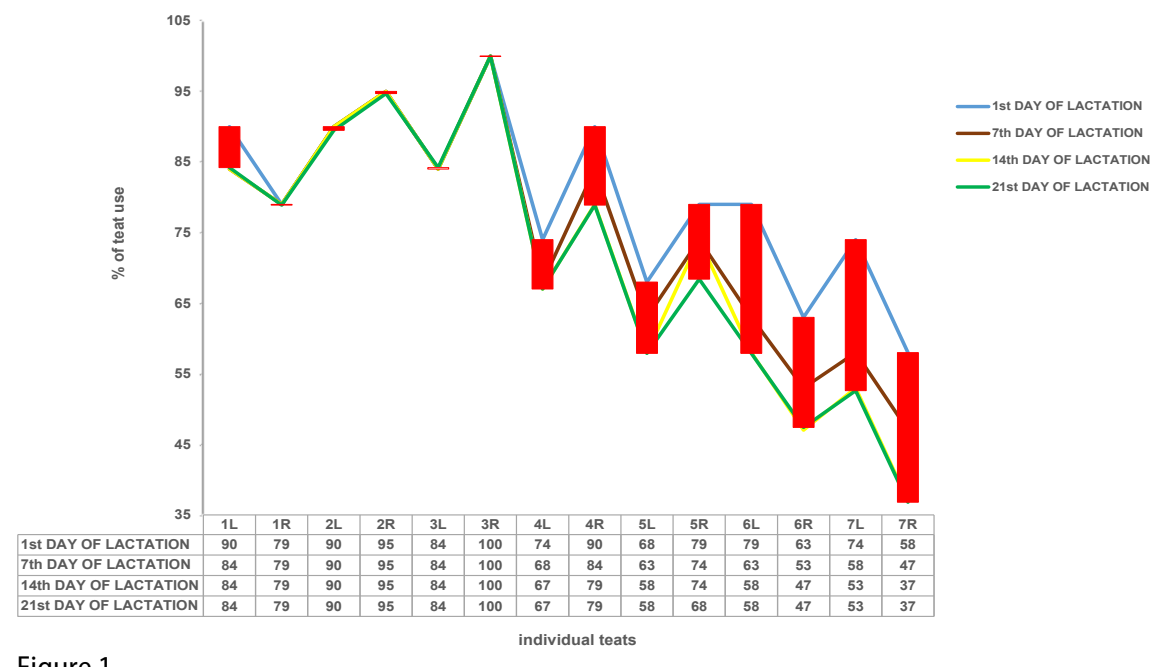

Figure 1

Piglet observations regarding preferences for individual teats

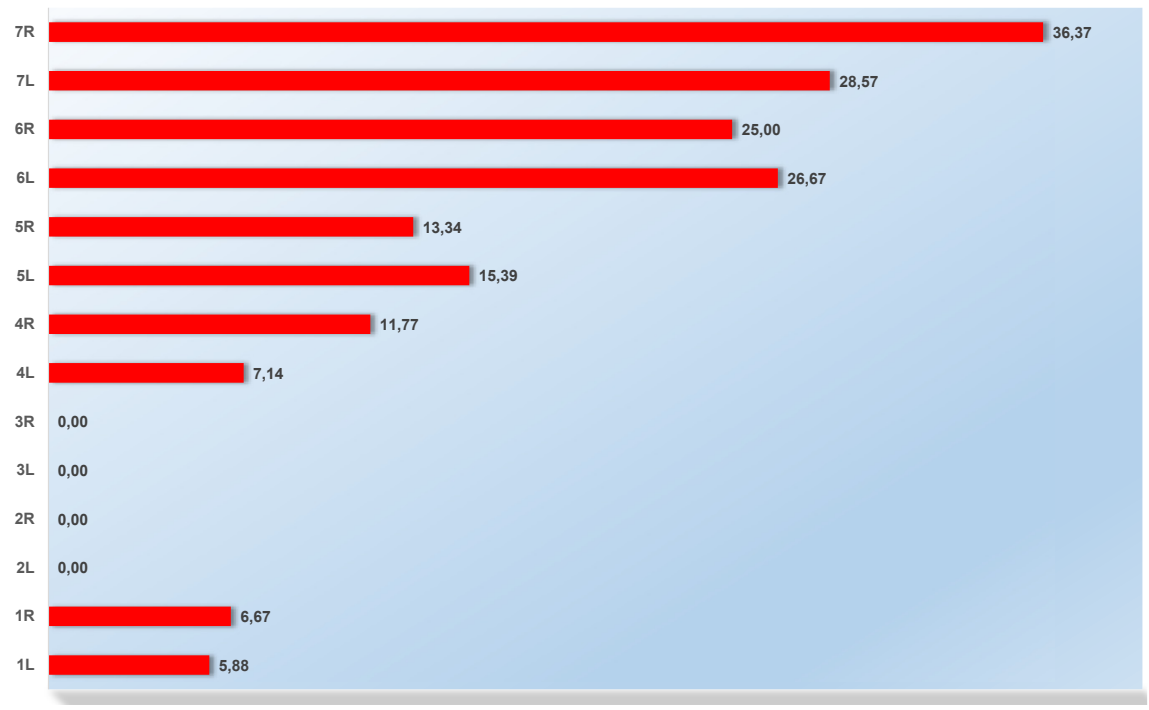

Figure 2

Mortality of piglets suckling individual teats, $\%$ 
Table 2 collates comparison of the weight of piglets in relation to the preferred teat. It was demonstrated that on the first day of lactation, piglets with the highest birth weight $(1.37 \mathrm{~kg})$ sucked from the second right teat $(2 \mathrm{R})$. Differences turned out to be statistically significant at the level of $P \leq 0.01$.

Table 2

Body weight of piglets depending on preferred teat

\begin{tabular}{|c|c|c|c|c|c|c|c|c|c|c|c|c|c|c|c|}
\hline Traits & & $\begin{array}{l}1 \text { left teat } \\
(1 \mathrm{~L})\end{array}$ & $\begin{array}{l}1 \text { right } \\
\text { teat }(1 R)\end{array}$ & $\begin{array}{l}2 \text { left teat } \\
\text { (2L) }\end{array}$ & $\begin{array}{l}2 \text { right } \\
\text { teat }(2 \mathrm{R})\end{array}$ & $\begin{array}{l}3 \text { left teat } \\
\text { (3L) }\end{array}$ & $\begin{array}{l}3 \text { right } \\
\text { teat (3R) }\end{array}$ & $\begin{array}{l}4 \text { left teat } \\
\quad(4 \mathrm{~L})\end{array}$ & $\begin{array}{l}4 \text { right } \\
\text { teat (4R) }\end{array}$ & $\begin{array}{l}5 \text { left teat } \\
\quad(5 \mathrm{~L})\end{array}$ & $\begin{array}{l}5 \text { right } \\
\text { teat (5R) }\end{array}$ & $\begin{array}{c}6 \text { left teat } \\
(6 \mathrm{~L})\end{array}$ & $\begin{array}{c}6 \text { right } \\
\text { teat }(6 \mathrm{R})\end{array}$ & $\begin{array}{l}7 \text { left teat } \\
\text { (7L) }\end{array}$ & $\begin{array}{l}7 \text { right } \\
\text { teat (7R) }\end{array}$ \\
\hline \multirow{2}{*}{$\begin{array}{l}\text { Body weight of } \\
\text { piglets at } 1 \mathrm{st}, \mathrm{kg}\end{array}$} & LSM & 1.34 & 1.31 & 1.33 & 1.37 & 1.24 & 1.27 & 1.19 & 1.20 & 0.98 & 1.08 & 0.87 & 0.99 & 0.92 & 0.98 \\
\hline & SE & $0.14^{\mathrm{A}}$ & $0.05^{\mathrm{A}}$ & $0.07^{\mathrm{A}}$ & $0.05^{\mathrm{A}}$ & $0.25^{\mathrm{A}}$ & $0.05^{\mathrm{A}}$ & $0.05^{\mathrm{AB}}$ & $0.05^{A B}$ & $0.05^{c}$ & $0.03^{\mathrm{CB}}$ & $0.19^{c}$ & $0.02^{C}$ & $0.03^{c}$ & $0.05^{c}$ \\
\hline \multirow{2}{*}{$\begin{array}{l}\text { Body weight of } \\
\text { piglets at } 7 \text { th, } \mathrm{kg}\end{array}$} & LSM & 2.59 & 2.37 & 2.53 & 2.44 & 2.24 & 2.34 & 2.23 & 2.06 & 1.79 & 1.81 & 1.96 & 1.76 & 1.68 & 1.86 \\
\hline & SE & $0.16^{B C}$ & $0.17^{B C E}$ & $0.26^{B C}$ & $0.17^{\mathrm{BE}}$ & $0.18^{\text {BCDEFG }}$ & $0.07^{\text {BCEG }}$ & $0.16^{\mathrm{ac}}$ & $0.11^{\mathrm{ab}}$ & $0.22^{\mathrm{AG}}$ & $0.35^{\mathrm{AF}}$ & $0.21^{\mathrm{ACE}}$ & $0.68^{\mathrm{ADbc}}$ & $0.54^{\mathrm{Abc}}$ & $0.19^{A C}$ \\
\hline \multirow{2}{*}{$\begin{array}{l}\text { Body weight of } \\
\text { piglets at } 14 \mathrm{th}, \mathrm{kg}\end{array}$} & LSM & 4.19 & 4.06 & 4.09 & 3.93 & 3.49 & 3.84 & 3.48 & 2.98 & 2.75 & 2.91 & 3.11 & 2.95 & 3.09 & 2.58 \\
\hline & SE & $0.29^{A C}$ & $0.30^{\mathrm{ACad}}$ & $0.27^{\text {ACad }}$ & $0.29^{\text {ACad }}$ & $0.27^{d}$ & $0.29^{c}$ & $0.31^{\mathrm{d}}$ & $0.30^{B C}$ & $0.35^{B C}$ & $0.28^{\mathrm{BC}}$ & $0.36^{B C b c}$ & $0.32^{\mathrm{BC}}$ & $0.31^{B C}$ & $0.34^{\mathrm{Ba}}$ \\
\hline \multirow{2}{*}{$\begin{array}{l}\text { Body weight of } \\
\text { piglets at } 21 \mathrm{th}, \mathrm{kg}\end{array}$} & LSM & 5.57 & 5.14 & 5.28 & 5.25 & 4.48 & 5.04 & 4.24 & 3.64 & 3.54 & 3.86 & 3.96 & 4.09 & 3.66 & 3.94 \\
\hline & SE & $0.39^{\text {Acd }}$ & $0.40^{A D}$ & $0.36^{A C}$ & $0.39^{A}$ & $0.36^{\mathrm{abc}}$ & $0.38^{A C b}$ & $0.42^{\mathrm{ab}}$ & $0.40^{\mathrm{B}}$ & $0.47^{B}$ & $0.38^{\mathrm{B}}$ & $0.48^{\mathrm{BC}}$ & $0.43^{\mathrm{BD}}$ & $0.44^{\mathrm{BCa}}$ & $0.48^{B D}$ \\
\hline
\end{tabular}

${ }^{\text {A-G } M e a n s ~ d i f f e r ~ s t a t i s t i c a l l y ~ s i g n i f i c a n t l y ~ a t ~} P \leq 0.01$, a-d Means differ statistically significantly at $P \leq 0.05$

Table 3

Growth rates of piglets depending on the preferred teat

\begin{tabular}{|c|c|c|c|c|c|c|c|c|c|c|c|c|c|c|c|}
\hline Traits & & $\begin{array}{c}1 \text { left } \\
\text { teat }(1 \mathrm{~L})\end{array}$ & $\begin{array}{l}1 \text { right } \\
\text { teat }(1 R)\end{array}$ & $\begin{array}{c}2 \text { left } \\
\text { teat }(2 \mathrm{~L})\end{array}$ & $\begin{array}{l}2 \text { right } \\
\text { teat }(2 R)\end{array}$ & $\begin{array}{c}3 \text { left } \\
\text { teat }(3 L)\end{array}$ & $\begin{array}{l}3 \text { right } \\
\text { teat (3R) }\end{array}$ & $\begin{array}{c}4 \text { left } \\
\text { teat }(4 \mathrm{~L})\end{array}$ & $\begin{array}{l}4 \text { right } \\
\text { teat }(4 \mathrm{R})\end{array}$ & $\begin{array}{c}5 \text { left } \\
\text { teat }(5 \mathrm{~L})\end{array}$ & $\begin{array}{l}5 \text { right } \\
\text { teat }(5 R)\end{array}$ & $\begin{array}{c}6 \text { left } \\
\text { teat }(6 \mathrm{~L})\end{array}$ & $\begin{array}{l}6 \text { right } \\
\text { teat }(6 R)\end{array}$ & $\begin{array}{c}7 \text { left } \\
\text { teat (7L) }\end{array}$ & $\begin{array}{l}7 \text { right } \\
\text { teat }(7 R)\end{array}$ \\
\hline \multirow{2}{*}{$\begin{array}{l}\text { Growth rate of piglets between } \\
\text { day } 1 \text { and } 7 \text { of life, kg }\end{array}$} & LSM & 1.24 & 1.05 & 1.19 & 1.06 & 0.98 & 1.06 & 1.03 & 0.84 & 0.78 & & 1.01 & 0.76 & 0.69 & 0.88 \\
\hline & SE & $0.14^{\mathrm{Aa}}$ & 0.15 & $0.14^{\mathrm{Aa}}$ & 0.15 & 0.14 & 0.15 & 0.16 & $0.15^{b}$ & $0.18^{b}$ & $0.14^{B}$ & 0.18 & $0.15^{b}$ & $0.15^{\mathrm{B}}$ & 0.17 \\
\hline \multirow{2}{*}{$\begin{array}{l}\text { Growth rate of piglets between } \\
\text { day } 8 \text { and } 14 \text { of life, } \mathrm{kg}\end{array}$} & LSM & 1.70 & 1.74 & 1.62 & 1.55 & 1.32 & 1.55 & 1.32 & 1.55 & 1.30 & 0.98 & 1.28 & 1.16 & 1.24 & 1.16 \\
\hline & $\mathrm{SE}$ & $0.18^{\mathrm{Aa}}$ & $0.19^{\text {Aa }}$ & $0.17^{\text {Aad }}$ & $0.18^{\mathrm{ac}}$ & 0.17 & $0.18^{\mathrm{ac}}$ & 0.20 & $0.19^{\mathrm{Bb}}$ & 0.24 & $0.19^{b c}$ & 0.24 & $0.18^{\mathrm{bcd}}$ & 0.23 & $0.20^{\mathrm{bcd}}$ \\
\hline \multirow{2}{*}{$\begin{array}{l}\text { Growth rate of piglets between } \\
\text { day } 15 \text { and } 21 \text { of life, kg }\end{array}$} & LSM & 1.37 & 1.07 & 1.18 & 1.32 & 0.99 & 1.19 & 0.76 & 0.77 & 0.77 & 0.94 & 0.83 & 1.13 & 0.90 & 1.11 \\
\hline & SE & $0.18^{\mathrm{a}}$ & 0.19 & 0.17 & $0.19^{\mathrm{ac}}$ & 0.17 & 0.18 & $0.20^{b}$ & $0.21 \mathrm{~b}$ & $0.22^{b}$ & 0.21 & $0.23 \mathrm{bc}$ & 0.20 & 0.21 & 0.23 \\
\hline \multirow{2}{*}{$\begin{array}{l}\text { Growth rate of piglets between } \\
\text { day } 1 \text { and } 21 \text { of life, } \mathrm{kg}\end{array}$} & LSM & 4.22 & 3.81 & 3.93 & 3.86 & 3.22 & 3.77 & 3.03 & 2.42 & 2.53 & 2.75 & 3.01 & 3.06 & 2.64 & 2.96 \\
\hline & SE & $0.37^{\mathrm{Aa}}$ & $0.38^{\mathrm{ACaC}}$ & $0.34^{A}$ & $0.37^{\mathrm{ACac}}$ & $0.34^{b c}$ & $0.37^{\mathrm{Aac}}$ & $0.40^{b c}$ & $0.38^{B D}$ & $0.45^{\mathrm{CDb}}$ & $0.36^{\text {BCbd }}$ & $0.46^{\mathrm{bcd}}$ & $0.40^{\mathrm{bcd}}$ & $0.42^{\mathrm{BCb}}$ & 0.46 \\
\hline
\end{tabular}

LSM: leat square means, SE: standard error, A-DMeans differ statistically significantly at $P \leq 0.01$, a-d Means differ statistically significantly at $P \leq 0.05$ 
Moving in the direction of the tail, the body weight of piglets was found to be increasingly lower and this tendency persisted throughout the analysed period with the highest weight $(5.57 \mathrm{~kg})$ recorded on day 21 of the experiment for piglets suckling from the first left teat $(1 \mathrm{~L})$. These differences were statistically significant at $P \leq 0.05$ and $P \leq 0.01$.

Table 3 collates data referring to body weight gain of piglets and their preferences for suckling from individual teats. The highest growth rates were recorded for piglets suckling teats from the first, second and third pair during the entire rearing period, i.e. from day 1 to day 21 . The highest body weight gain $(4.22 \mathrm{~kg})$ was observed in the case of piglets suckling the first left teat $(1 \mathrm{~L})$.

Analysing consecutive weeks of piglets' body weight gain, the greatest statistically significant differences at $P \leq 0.05$ and $P \leq 0.01$ were recorded between the 8th and 14th day of lactation (2nd week of lactation).

Bearing individual weights of piglets as well as their body weight gain in mind, it can be said that the most active piglets (dominants) and those with the highest birth weight suckled the front and central teats.

Figure 3 presents quantities of milk $(\mathrm{kg})$ secreted by individual teats of sows. It was demonstrated that the highest milk yield $(16.9 \mathrm{~kg})$ was produced by the first left teat $(1 \mathrm{~L})$ and the smallest milk yield $(9.71 \mathrm{~kg})$ from the fourth right teat $(4 \mathrm{R})$.

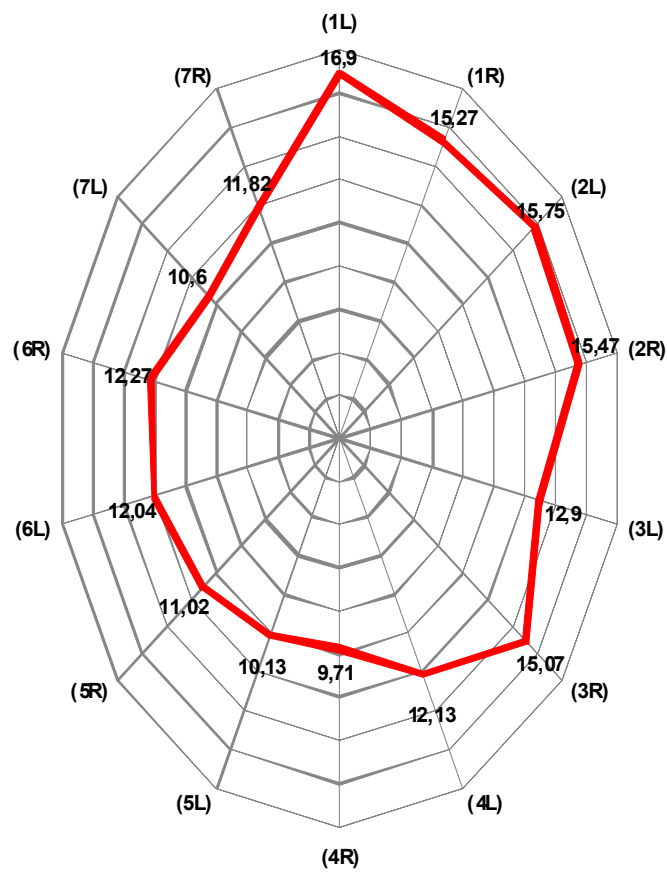

Figure 3

Milk yields of individual teats from day 1 to 21 of lactation, $\mathrm{kg}$

On the basis of the performed experiments, it can be concluded that teats of the first three pairs, secreting the highest milk yield, were preferred by the heaviest piglets.

Mean body weight gain of piglets in the analysed periods as well as the vitality of piglets suckling front teats of sows were higher in comparison with the gain and vitality of piglets utilising the rear areas of the mammary glands. 


\section{Discussion}

Scientists have been involved in investigations aiming to elucidate differences in body weight gain of piglets suckling consecutive teats and the existence of a specific association of piglets with consecutive pairs of teats. The birth body weight of piglets as well as the ability to suckle colostrum and milk are major factors influencing survivability of piglets during the suckling period, their growth rate and the body weight at weaning (Revell et al. 1998, Szulc et al. 2011, Babicz et al. 2012). Piglets' birth body weight as well as the number of piglets are influenced by many factors and fluctuate within wide boundaries. The mean weight of piglets in our investigations ranged from $0.87 \mathrm{~kg}$ to $1.37 \mathrm{~kg}$ on day 1 of life, and on day 21 it ranged from $3.54 \mathrm{~kg}$ to $5.57 \mathrm{~kg}$.

In practice, it is desirable to equalise the body weight of piglets in a litter because its high variability leads to greater mortality in rearing (Buczyński et al. 2008). Also Skorjanc et al. (2007) reported that piglet's growth rate during the lactation period was non-linear. Piglets with the highest birth weight slow down rapidly their growth rates in the 3rd and 4th weeks of lactation. Piglets whose birth weight is less than $1 \mathrm{~kg}$ have a small chance of survival (Smith et al. 2007).

The difference between the heaviest and the lightest piglet in the discussed investigations in the course of the analysed period amounted to $2.03 \mathrm{~kg}$.

The development and rearing results of piglets depend to a considerable extent on the specific relationship of piglets with consecutive teats of the mother-sow, i.e. on the so called "teat order" (Mason et al. 2003). The results presented in this paper confirm that piglets of the highest weight used front regions of the mammary gland leaving rear teats to weaker and smaller piglets. The above observations are corroborated in literature by other researchers (Dyck et al. 1987, Puppe \& Tuchscherer 1999, Kim et al. 2000, Wu et al. 2010).

In their experiments, Nielsen et al. (2001) demonstrated that the growth rate of piglets depended on teat location but only in multipara sows, whereas this relationship was not found in primipara sows. Our investigations corroborated this dependence because all sows taking part in the trial were multipara in the 3rd lactation.

Different results were reported by Mardarowicz (1988), who claimed that the heaviest piglets suckled from front and rear teats leaving the central area to weaker and smaller piglets. Migdał \& Klocek (1996) as well as Puppe \& Tuchscherer (2000) believe that the existence of hierarchical systems among piglets is strongly associated with udder zones. Auldist et al. (2000) maintain that milk yields from individual teats can depend on suckling frequency which is corroborated by Migdał et al. (1990) who proved that teats situated in the front part of the sow body produced more milk and most probably this fact contributed to varying usage of these teats by piglets. The research results obtained in this study confirmed observations made by the above-mentioned researchers. Piglets suckling teats from the front part of the sow body were characterised by the highest weight, body weight gain and the smallest number of death. In addition, the recorded milk yields were highest from teats situated in the front part of the body trunk.

According to Foisnet et al. (2010), mortality below $15 \%$ in the period before weaning falls within physiological limits. It can be assumed that high piglet losses recorded in our investigations could have been caused by worse quality of milk from rear teats. 
Taking into consideration milk yields recorded for individual teats, it was proved that front teats produced more milk than inguinal teats. This observation was also corroborated by investigations carried out by Fraser et al. (1992), Auldist et al. (1998) and Rząsa et al. (2003).

In conclusion, the performed experiments confirmed that piglets suckling teats located in the front part of the mammary gland (1st, 2nd and 3rd pair) were characterised by the highest growth rate during the entire course of the experiment.

Recapitulating the performed investigations, it was demonstrated that teat location affected body weight, growth rate and mortality of piglets. Teats of the 2nd and 3rd pairs were utilised by piglets most frequently, while those situated close to the tail were suckled more rarely and mainly by marginal piglets. It was further demonstrated that the highest losses in litters were recorded among piglets which used rear mammary glands. Milk yield from front teats also turned out to be the highest.

\section{References}

Auldist DE, Morrish L, Eason P, King RH (1998) The influence of litter size on milk production of sows. Anim Sci 67, 333-337

Auldist DE, Carlson D, Morrish L, Wakeford CM, King RH (2000) The influence of suckling interval on milk production of sows. J Anim Sci 78, 2026-2031

Babicz M, Skrzypczak E, Rejduch B, Kozubska-Sobocińska A, Chmielowiec-Korzeniowska A, Kasprzak K (2012) Effect of Thermal Stress on Reproductive Performance Parameters of Sows with Defined Genotype at the RYR1 locus. Ann Anim Sci 12, 323-333

Baxter EM, Jarvis S, Sherwood L, Farish M, Roehe R, Lawrence AB, Edwards SA (2011) Genetic and environmental effects on piglet survival and maternal behaviour of the farrowing sow. Appl Anim Behav Sci 130, 28-41

Beyga K, Rekiel A (2009) Effect of the backfat thickness of sows in late pregnancy on the composition of colostrum and milk. Arch Tierz 52, 593-602

Beyga K, Rekiel A (2010) The effect of the body condition of late pregnant sows on fat reserves at farrowing and weaning and on litter performance. Arch Tierz 53, 50-64

Buczyński JT, Skrzypczak E, Panek A, Szulc K, Niedzielska M (2008) [Effect of chemical composition of sow milk on rearing performance of Złotnicka White piglets]. Rocz Nauk Zoot 35,11-17 [in Polish]

Burri M, Wechsler B, Gygax L, Weber R (2009) Influence of straw length, sow behaviour and room temperature on the incidence of dangerous situations for piglets in a loose farrowing system. Appl Anim Behav Sci $117,181-189$

Devillers N, Farmer C, Le Dividich J, Prunier A (2007) Variability of colostrum yield and colostrum intake in pigs. Animal 1, 1033-1041

Dyck GW, Swierstra EE, McKay RM, Mount K (1987) Effect of location of the teat suckled, breed and parity on piglet growth. Can J Anim Sci 67, 929-939

Eliasson C, Isberg S (2011) Production and composition of sow milk. Literature Review, Swedish University of Agricultural Sciences, Uppsala, Sweden, 1-10

Foisnet A, Farmer C, David C, Quesnel H (2010) Relationships between colostrum production by primiparous sows and sow physiology around parturition. J Anim Sci 88, 1672-1683

FraserD, Thompson BK, Rushen J (1992) Teat productivity in second lactation sows: influence of use or non-use of teats during the first lactation. Anim Prod 55, 419-424

Górecki MT (2003) Sex ratio in litters of domestic pigs (Sus scrofa f. domestica Linnaeus, 1758). Biol Lett 40, $111-118$ 
Jensen P, Gustafsson M, Augustsson H (1998) Teat massage after milk ingestion in domestic piglets: an example of honest begging? Anim Behav 55, 779-786

Kim JS, Jin DI, Lee JH, Son DS, Lee SH, Yi YJ, Park CS (2005) Effects of teat number on litter size in gilts. Anim Reprod Sci 90, 111-116

Kim SW, Hurley WL, Hant IK, Easter RA (2000) Growth of nursing pigs related to the characteristics of nursed mammary glands. J Anim Sci 78, 1313-1318

King RH, Mullan BP, Dunshea FR, Dove H (1997) The influence of piglet body weight on milk production of sows. Livest Prod Sci 47, 169-174

Komosa M, Purzyc H (2009) Konik and Hucul horses: A comparative study of exterior measurements. J Anim Sci 87, 2245-2254

Le Dividich J, Rooke JA, Herpin P (2005) Nutritional and immunological importance of colostrum for the newborn pig. J Agric Sci 143, 469-485

Lundgren H (2011) Genetics of Sow Performance in Piglet Production. Doctoral Thesis. Swedish University of Agricultural Sciences, Acta Universitatis agriculturae Sueciae 91, 1-53

Lynch M, Welsh B (1998) Genetics and analysis of quantitative traits. Sinauer Assoc Inc, Sunderland, Massachusetts, USA

Mardarowicz L (1988) [Piglet behaviour during the post-parturition period]. Med Wet 10, 615-619 [in Polish]

Mason SP, Jarvis S, Lawrence AB (2003) Individual differences in responses of piglets to weaning at different ages. Appl Anim Behav Sci 80, 117-132

Migdał W, Kaczmarczyk J, Koczanowski J, Klocek C, Tuz R (1990) [Teat order and swine rearing results]. Zesz Nauk AR Krak 242, 83-99 [in Polish]

Migdał W, Klocek C (1996) Chemical composition of milk collected from different sow teats and the results of piglet rearing. Acta Agricult Acad Tech Olst 23,155-159

Nielsen OL, Pedersen AR, Sørensen MT (2001) Relationships between piglet growth rate and mammary gland size of the sow. Livest Prod Sci 67, 273-279

Pejsak Z (2006) [Colostrum as the source of vitality and passive immunity in suckling piglets]. Życie Wet 81, 588-591 [in Polish]

Polish Nutrient Requirements for Pig (1993) The Kielanowski Institute of Animal Physiology and Nutrition, Jabłonna (Poland). Omnitech Press. Warsaw [in Polish]

Puppe B, Tuchscherer A (1999) Developmental and territorial aspects of suckling behaviour in the domestic pig (Sus scrofa f. domestica). J Zool 249, 307-313

Puppe B, Tuchscherer A (2000) The suckling behaviour in the domestic pig: modeling and behavioural consequences. Arch Tierz 43, Special Issue, 233

Quesnel H (2011) Colostrum: roles in piglet performance and production by the sow. VI SINSUI - Simposio Internacional de Suinocultura, Porto Alegre, RS, Brazil, 1-12

Revell DK, Williams IH, Mullan BP, Ranford JL, Smits RJ (1998) Body composition at farrowing and nutrition during lactation affect the performance of primiparous sows: Il. Milk composition, milk yield, and pig growth. J Anim Sci 76, 1738-1743

Rooke JA, Bland IM (2002) The acquisition of passive immunity in the new-born piglet. Livest Prod Sci 78, 13-23

Rosiński A, Nowaczewski S, Kontecka H, Samolak J, Bielińska H, Badowski J (2006) Analysis of the laying rhythm in White Koluda ${ }^{\oplus}$ geese. Arch Geflügelk 70,187-192

Rząsa A, Poznański W, Akińcza J, Procak A (2003) The effect of teat order on piglet rearing results. Ann Anim Sci (Suppl.), 99-103

SAS (2007) User's Guide, version 8.11. SAS Inst. Inc., Cary, NC, USA

Skrzypczak E, Babicz M , Szulc K, Walendowska A, Panek A (2012) Impact of Sow Milk Protein Polymorphism on Piglet Rearing. Ann Anim Sci 12, 335-347 
Škorjanc D, Brus M, Čandek Potokar M (2007) Effect of Birth Weight and Sex on Pre-Weaning Growth Rate of Piglets. Arch Tierz 50, 476-486

Smith AL, Stalder KJ, Serenius TV, Baas TJ, Mabry JW (2007) Effect of piglet birth weight on weights at weaning and 42 days post weaning. J Swine Health Prod 15, 213-218

Stabenow B, Manteuffel G (2002) A better welfare for nursing sows without increased piglet loss applying peri-parturition short term crating. Arch Tierz 45, 53-60

Szulc K, Skrzypczak E, Panek A, Knecht D, Jankowska A, Sobek Z, Stanisławski D (2011) Analysis of reproduction and litter performance of the Złotnicka Spotted breed and its different crossbreeds. Ital J Anim Sci 10, 184-187

Szulc K, Skrzypczak E, Buczyński JT, Stanisławski D, Jankowska-Mąkosa A, Knecht D (2012) Evaluation of fattening and slaughter performance and determination of meat quality in Złotnicka Spotted pigs and their crosses with the Duroc breed. Czech J Anim Sci 57, 95-107

Tvrdon Z, Humpolicek P (2010) Impact of hyper-prolific population generation on the reproduction of sows in multiplication herds. Arch Tierz 53, 176-183

Vanheukelom V, Driessen B, Geers R (2012) The effects of environmental enrichment on the behaviour of suckling piglets and lactating sows: A review. Livest Sci 143, 116-131

Wähner M, Scholz H, Kämmerer B (2001) [Relationship between feed intake, side fat thickness and special parameters of rearing performance of lactating sows]. Arch Tierz 44, 639-648 [in German]

Williams IH (1995) Sow's milk as a major nutrient source before weaning. In: Hennessy DP, Cranwell PD (Eds.) Manipulating Pig Production V: Proc 5th Biennal Conf APSA held in Canberra, ACT, Australia, 107-113

Wu WZ, Wang XQ, Wu GY, Kim SW, Chen F, Wang JJ (2010) Differential composition of proteomes in sow colostrum and milk from anterior and posterior mammary glands. J Anim Sci 88, 2657-2664

Żuk B (1989) [Applied biometry]. PWN, Warszawa, Poland [in Polish] 